\title{
Bactericidal/Permeability-Increasing Protein Antibody Measurement
}

National Cancer Institute

\section{Source}

National Cancer Institute. Bactericidal/Permeability-Increasing Protein Antibody

Measurement. NCI Thesaurus. Code C120631.

The determination of the bactericidal/permeability-increasing protein antibody present in a sample. 